\title{
Contributions of Dr. McCrone to Criminalistics
}

\author{
Wayne Moorehead, MS, F-ABC \\ Forensic Scientist \\ 7 Boxthorn \\ Rancho Santa Margarita, CA 92688
}

One could successfully argue that Dr. McCrone's work in criminalistics began in 1942 when he completed his $\mathrm{Ph}$.D. dissertation on the identification of chemicals through fusion methods which involves their recrystallization from a melt or his post-doctoral work in the microscopy of explosives [1]. Reportedly sometime in 1960 or 1961, Jack Cadman, one of the founders of the California Association of Criminalists (CAC), heard of Dr. McCrone's remarkable ability in microscopy and invited him to a meeting that Beckman Instruments was conducting on instrumentation used to combat crime [2]. It may have been at this meeting that Dr. McCrone was formally introduced to the world of criminalistics. In early 1962, Dr. McCrone became a member of the American Academy of Forensic Science (AAFS) where Chicago was host to the AAFS annual meeting. By 1967, Dr. McCrone gained the status of Fellow member in the Academy and was a member until his untimely death in 2002 [3].

A prolific writer of articles, chapters, and books, Dr. McCrone often wrote on the subject of microscopy and its application to criminalistics. Published in 1967, he co-authored the first edition of The Particle Atlas [4]. Its applicability to the criminalist was noted in the Acknowledgement, in the Introduction and in a 1968 advertisement for the Atlas in the journal The Microscope. The Particle Atlas Edition Two (PAET) greatly expanded the number of particles characterized. It included both optical and electron microscopy, and incorporated elemental data on the particles [5]. Dr. McCrone devoted an entire chapter to a comprehensive outline of analysis for 10 common trace evidence categories with applicable chapters to criminalistics on microchemical reactions and the geographical origins of dust. The Particle Atlas Electronic Edition on CD contains the same information in PAET but permits searches against the database of various optical, physical, and other properties of substances. In 1986 he wrote the chapter Forensic Microscopy in the book by Davies [6]. When the journal The Microscope was purchased in 1963, Dr. McCrone became its editor and had doubled in size by 1967. The Microscope routinely features articles of great value to the forensic microscopist (as well as all particle microscopists) and it publishes the abstracts of the Inter/Micro meetings with an annotation of each presentation given below the abstract.

The McCrone Research Institute (MRI) was the primary leader in classes and teaching of forensic microscopy since at least as early as 1968. During that year the MRI advertised the course "Microscopy in the Crime Laboratory" in The Microscope [7]. In addition to the regularly scheduled microscopy classes at MRI, they acquired Law Enforcement Assistance Administration (LEAA) grants in the late 1970's to teach polarized light microscopy to criminalists across the nation with Dr. McCrone providing most of the instruction. Over the years many thousands of criminalists have been taught or have been given guidance in microscopy and microscopical matters by Dr. McCrone. His unique method of teaching awakened in his students the self-realization that their education wasn't over, it was just beginning - creating in the student a curiosity about the microscopic world around them. 
He readily promoted and supported professionalism in criminalistics. From 1975 to 1979 a National Institute of Justice grant was awarded to a national committee, the Criminalistics Certification Study Committee (CCSC), to research and formulate a certification procedure for individuals in criminalistics. Dr. McCrone was among the first to join that initial committee. This first effort failed, but they had planted a seed. By the mid 1980's the CAC established its own certification program for criminalists. In 1989 the visionary Dr. McCrone realized that factors were near congruence and he designed a plan. At his own expense, he invited the CAC Certification Committee chair, former members of the CCSC committee, and those with influence in the criminalistics community to a meeting to discuss the implementation of a national certification program for criminalists. This meeting created the launching point for the American Board of Criminalistics, the premier body for the certification of criminalists [8].

Dr. McCrone provided expertise in several high profile forensic cases. One of the best-known criminal cases was the Atlanta Child Murders with Wayne Williams suspected of killing 29 young men and boys. Additionally, Dr. McCrone worked on numerous items of art determining fraud or authenticity, the Vinland Map and the Shroud of Turin being the most notables. Even here, Dr. McCrone set the tone for ethics and philosophy for criminalists: document your analysis, maintain your professional demeanor even when other scientists disagree with your conclusions, and maintain your integrity.

He received awards for his work in criminalistics beginning in 1982 with the Certificate of Merit from the Forensic Science Foundation. In 1984 he received The Paul Kirk Distinguished Service Award from the Criminalistics section of the American Academy of Forensic Sciences, in 1990 he provided the Founder's Lecture to the CAC, and in 1991 received the Roger Greene award from the CAC.

Dr. McCrone changed the philosophy of particle evidence analysis by showing how methods and techniques in unrelated microscopical areas can be applied to answering questions posed about trace evidence. His publications, microscopical knowledge, energy, enthusiasm, and guidance were inspiring to all that knew him. Dr. McCrone will be missed.

[1] W. McCrone, et al., Report on the Microscopic Examination of High Explosives and Boosters, Cornell University, August 1944

[2] Personal communication, Jack Cadman, January 23, 2003

[3] Personal communication, Kimberly Rossi, American Academy of Forensic Science, February 3, 2003

[4] W. McCrone, et al., The Particle Atlas, $1^{\text {st }}$ Ed., Ann Arbor Science Publishers, Inc., Ann Arbor, Michigan, 1967

[5] W. McCrone, et al., The Particle Atlas Edition Two, Vol. I - VI, Ann Arbor Science Publishers, Inc., Ann Arbor, Michigan, 1973 - 1979

[6] W. McCrone, Forensic Microscopy, in G. Davies (editor), Forensic Science, $2^{\text {nd }}$ ed., American Chemical Society, Washington, DC, 1986

[7] The Microscope, 16 (1968) 200

[8] History section of ABC website, http://criminalistics.com/abc/B.A.A.php, December 2002 [9] This research was partially supported by the Orange County Sheriff-Coroner Department Forensic Science Services. The assistance of Director Frank Fitzpatrick is gratefully acknowledged. 